\title{
Comparison of Multifidus Muscle Activity and Pelvic Tilting Angle During Typing in Nonspecific Lower Back Pain Subjects with and without Visual Biofeedback
}

In-Cheol Jeon

Department of Physical Therapy, College of Life and Health Science, Hoseo University, Research Institute for Basic Sciences, Hoseo University, Asan, Republic of Korea

Purpose: Biofeedback using various ways has helped correct the sitting posture. This study compared the multifidus muscle activity, pelvic and 2nd sacrum tilting angle during typing in nonspecific lower back pain (NCLBP) subjects with and without visual biofeedback. Methods: Thirty subjects with NCLBP were enrolled in this study. An electromyography device was used to measure the multifidus muscle activity. An electromagnetic tracking motion device was used to measure the pelvic and 2 nd sacrum tilting angle. The multifidus muscle activity, pelvic, and 2nd sacrum tilting angle were measured before and after typing for 30 minutes in the sitting position. An independent $t$-test was used to compare the changing values for 30 minutes between the group with and without visual biofeedback. Results: The changing values of the multifidus muscle activity, pelvic, and 2nd sacrum tilting angle were significantly smaller in the group with visual biofeedback than the group without visual biofeedback $(p<0.05)$.

Conclusions: In subjects with NCLBP, the visual biofeedback can be recommended to maintain the multifidus muscle activity, pelvic, and 2nd sacrum tilting angle during typing for 30 minutes.

Keywords: Multifidus, Pelvic tilting angle, Sacrum tilting angle, Typing, Visual biofeedback

서 론

컴퓨터 앞에 앉아서 장시간 동안 일하는 작업은 요통을 일으킬 가능 성이 높다.' 이러한 악영향을 주는 자세 중에 구부정한 앉은 자세 (slump sitting position)를 예로 들 수가 있는데, 이 자세는 특히 요통을 악화시킬 수 있다. ${ }^{2}$ 허리뼈를 굽힐 때 통증이 있는 환자의 비특이성 만성 요통(nonspecific chronic lower back pain, NCLBP)에 대한 연구가 많이 진행되었다.1.2 장시간 앉아 있는 동안 허리뼈 앞굽음 곡선 감소 와 척추세움근과 같은 몸통 근육 활동이 감소된다는 사실이 입증되 었다.3.4 특히 허리뼈 굽힘이 과도하게 발생된 채 의자의 모서리 끝에 걸쳐서 앉아있는 자세는 척추의 조직 손상을 유발할 수 있다. ${ }^{5,6}$ 장시 간 동안 일을 수행하면서, 최적의 앉은 자세가 무너지기가 쉬운데, 특 히 요통 환자는 최적의 허리뼈 앞굽음 곡선과 골반 전방 기울임을 유 지하는 데 더 큰 어려움을 호소하는 것으로 밝혀졌다. ${ }^{6}$

허리골반앉기(lumbo-pelvic sitting)를 통해 등뼈를 포함한 몸통 부
위는 편안한 상태를 유지하고, 허리골반 부위에서 적절한 허리뼈 앞 굽음과 골반 전방 기울임을 유지함으로써 곧게 선 앉은 자세(upright sitting posture)를 하면 배속빗근 표면 부위의 뭇갈래근이 활성화 될 수 있다고 밝혔다. 따라서 곧게 선 앉은 자세를 통해 훈련이 된다면, 장시간 앉아있는 동안에 뭇갈래근과 배속빗근의 공동 활성화(co-activation)를 증가시키기 때문에, 허리골반 부위가 후방 기울임 되면서 발생할 수 있는 허리뼈 부위스트레스를 줄일 수 있다. 뭇갈래근을 포 함한 척추 안정화 근육과 같은 능동적 구조물들의 활성화가 감소하 면, 곧게 선 앉은 자세가 구부정한 앉은 자세로 바뀌면서, 능동적 안정 화 기능은 감소되고, 인대와 같은 수동적 구조물을 통한 자세적 기여 가 증가되면서, 척추의 하중이 뒤쪽 방향으로 이동하게 된다. 이러한 상태가 장시간 그리고 빈번하게 노출이 되면 요통을 유발할 수 있다. 일반적으로 비특이성 요통을 관리하기 위해 적절한 골반 전방 기 울임, 허리뼈 앞굽음 및 몸통 부위의 중립 상태로 앉도록 하는 것이 상당히 중요하다. 임상적으로 보면, 앉아있는 동안 자세 운동 조절이 
부족하거나, 좋은 자세를 유지하기 위해 의식적으로 많은 노력이 필 요하다면, 이것은 장시간 앉아있는 상황에 노출될수록 앉은 자세가 안좋게 바뀔 수 있다. ${ }^{8}$ 지금까지의 선행연구들을 살펴보면, 허리뼈의 자세 교정에 대한 피드백을 위해 키네시오 테이핑과 같은 다양한 종 류의 테이핑 기법을 사용해 왔다. ${ }^{29}$ 이러한 테이핑 기법들을 통해 앉 은 자세에 대한 피드백 제공이 척추관절의 정렬을 유지하는데 효과 적이라고 보는 연구가 대부분이었다.29.11 테이핑을 하지 않은 그룹에 비해서, 적용한 그룹에서 자세 근육 활성도를 향상시키고, 뒤쪽으로 기울어진 허리골반부위와 연관된 통증을 감소시키며, 허리뼈의 굽힘 을 감소시키는데 더욱 효과적이었다."1

하지만 이러한 테이핑은 임상적으로 적용이 용이함에도 불구하 고, 장시간 동안 피부에 직접적으로 부착이 되기 때문에 피부 간지러 움 또는 발진의 부작용을 보이기도 한다. 또한, 피부에 직접적으로 붙 여서 인대와 같은 수동적 구조물과 같은 역할을 보조해 주는 역할을 하기 때문에 능동적 근활성도 증가와 같이 긍정적인 영향을 주기에 는 한계가 있다. 따라서 본 연구에서는 이러한 제한점을 보완하고, 피 부에 직접적인 부착으로 인한 피부자극에서 자유로우며, 뭇갈래근 과 같은 능동적 구조물의 개입을 향상시킬 수 있는 시각적 바이오 피 드백을 이용하여 실험을 진행하려 한다.

시각적 바이오 피드백은 앉은 자세에서 건강한 대상자 또는 환자 를 대상으로 한 연구가 많이 진행되어 왔는데, 특히 비특이성 요통 대 상자에게 실시간으로 시각적 바이오 피드백을 제공하는 것이 앉은 자세에 대한 자세 인식(positional awareness)을 향상시키는데 효과적 이라는 것이 연구되었다.9-11 또한 앉은 자세에서 향상된 자세 인식을 통한 충분한 몸통 조절 능력은 허리골반 부위 안정성에 큰 기여를 한 다고 밝혀졌다. ${ }^{10}$

지금까지의 연구를 보면, 비특이성 요통이 있는 대상자가 앉아있 는 자세에서 타이핑을 수행하는 동안에 뭇갈래근 근활성도 변화와 골반 기울임 각도에 대해서 시각적 바이오 피드백의 제공이 미치는 영향은 조사되지 않았다. 본 연구의 목적은 30 분 동안 컴퓨터 앞에 앉아 타이핑을 수행하는 동안 비특이성 요통 대상자에서 시각적 바 이오 피드백 제공이 뭇갈래근의 근활성도와 골반 그리고 2 번째 엉치 뼈 기울임 각도에 어떠한 영향을 미치는지 조사하는 것이다. 이 연구 의 가설은 시각적 바이오 피드백 제공 그룹에서 뭇갈래근 근활성도, 골반 그리고 2 번째 엉치뼈 기울임 각도의 30 분간의 변화값이 비제공 그룹과 비교하여 유의한 차이가 있을 것이다라고 설정하였다.

\section{연구방법}

\section{1. 연구대상}

35 명의 비특이성 만성요통이 있는 대상자가 참여하였다. 제외 기준에
따라 5 명의 대상자가 탈락 하였고, 비특이성 만성요통이 포함된 30 명(바이오 피드백 제공 그룹 15명, 바이오 피드백 비제공 그룹 15명) 을 선발하였다. 최소 3 개월 이상 지속된 비특이성 만성요통을 호소하 고, 안정 시에도 시각적 아날로그 스케일은 3점 이상인 대상자가 참 가하였다.12.13 허리뼈 굽힘 자세에서 비특이성 요통이 악화되고, 통증 부위에 정상적인 허리앞굽음이 소실된 상태이다. 또한 허리뼈 굽힘이 감소하면서, 통증 증상이 없거나 감소하는 상태이다. ${ }^{14}$ 제외 기준은 1$)$ 허리뼈 골절, 2) 하지 또는 허리의 수술, 3) 운동으로 인한 허리뼈 통증 증상의 악화, 4) 허리뼈 및 엉덩관절 구축, 신경계 질환,5) 자세에 따른 과도한 앞굽음증, 6) 임신으로 정하였다. 대상자의 일반적인 정보는 Table 1과 같다. 연구를 진행하기 전에 대상자들에게 실험절차를 자 세히 설명하고 동의를 구했다. 모든 참가자는 사전 동의 양식에 서명 했다.

\section{2. 실험방법}

\section{1) 측정방법 및 도구}

(1) 근활성도

표면 근전도 기기를 사용하여 뭇갈래근 근활성도를 도출했다. 근전 도데이터의 2개 채널은 근전도 분석 하드웨어(Noraxon TeleMyo 2400T, Noraxon, Scottsdale, USA)를 사용하여 수집했고, 소프트웨어 (MyoResearch XP Master Edition 1.06, Noraxon, USA)를 사용하여 분 석했다. 근전도 데이터는 $1,000 \mathrm{~Hz}$ 에서 샘플링되었고 대역 통과는 20 $\mathrm{Hz}$ 에서 $250 \mathrm{~Hz}$ 로 설정하였다. 표면 근전도 패치는 양극성 $\mathrm{Ag} / \mathrm{AgCl}$ 의 일회용 전극을 뭇갈래근 양쪽에 배치했다. 전극을 적용하기 전에 피부를 면도하고 알코올로 세척하여 표면 저항을 줄였다. ${ }^{15}$ 전극을 뭇 갈래근 $\left(4\right.$ 번 허리뼈의 가시 돌기 측면 $2 \mathrm{~cm}$ )에 적용했다. ${ }^{16}$

근전도 데이터는 타이핑 작업 시작 전 측정값과 30 분 타이핑 완료 후 측정값을 빼서 뭇갈래근 근활성도에 대한 변화값(changing value) 을 도출했다. 시작 전과 30 분 타이핑을 수행한 이후 자세에서 5 초를 각각 측정하였고, 그 중 중간 3 초를 사용했다. 비특이성 요통이 있는 대상자에게는 등척성 최대하 자발적 수축(sub-maximal voluntary contraction, sub-MVIC)을 이용해서 적용하였다. ${ }^{7}$ 뭇갈래근의 subMVIC를 측정하기 위해 "double bent knee lift"가 사용되었다. 피실험 자는 엎드린 자세로 무릎을 $90^{\circ}$ 구부리고 양 무릎을 땅에서 3 초 동안

Table 1. Subject characteristics

\begin{tabular}{lrrrr}
\hline Variables & $\begin{array}{c}\text { Biofeedback } \\
\text { group }\end{array}$ & $\begin{array}{c}\text { Non biofeedback } \\
\text { group }\end{array}$ & $\mathrm{t}$ & $\mathrm{p}$ \\
\hline Age $(\mathrm{yr})$ & $24.2 \pm 3.6$ & $23.5 \pm 4.7$ & 1.57 & 0.345 \\
Height $(\mathrm{cm})$ & $167.4 \pm 4.1$ & $170.1 \pm 5.5$ & -1.13 & 0.468 \\
Weight $(\mathrm{kg})$ & $53.2 \pm 6.3$ & $54.1 \pm 7.6$ & -1.04 & 0.657 \\
\hline
\end{tabular}

${ }^{*} \mathrm{p}<0.05$, Mean \pm Standard deviation. 
$5 \mathrm{~cm}$ 들어 올렸다. 모든 데이터는 3 회 측정 되었으며, 각 시험에서 10 초 동안 휴식을 취했다.17

(2) 골반 기울임 각도

본 연구에서는 골반경사 측정기(Performance Attainment Associates, PALM, St Paul, USA)를 사용하여 신체의 위앞엉덩뼈가시(anterior superior iliac spine, ASIS)와 위뒤엉덩뼈가시(posterior superior iliac spine, PSIS) 사이의 기울임 각도를 앉은 자세에서 측정했다. 기울임계는 정 중선에서 어느 방향으로든 $0-30^{\circ}$ 범위 내에서 $1^{\circ}$ 간격으로 이동할 수 있는 반원 호를 사용한다. 골반경사 측정기를 이용해 골반 기울임 각 도를 측정한 급내상관계수(intraclass correlation coefficient)는 0.920.99 이다. ${ }^{18}$

시작 자세는 골반경사 측정기를 이용해서 위앞엉덩뼈가시 그리고 위뒤엉덩뼈가시 사이를 시상면을 기준으로 골발 기울임 각도를 0 도 로 맞춰놓았다. 앉은 자세에서 30 분간 타이핑 작업을 한 후 골반 기울 임을 측정했다. 지시손가락을 이용해 동측 위앞엉덩뼈가시와 위뒤엉 덩뼈가시의 돌출부를 촉진하였다. 시상면에서 골반 기울임 각도를 측정하기 위해 수행되었다. 전방 골반 기울임은 플러스 (+) 값을 나타 내고, 후방 골반 기울임은 마이너스 (-) 값을 나타냈다. 30 분 타이핑 후 동측 위앞엉덩뼈가시와 위뒤엉덩뼈가시 사이의 기울임 각도를 골반 경사 측정기로 측정했다.

\section{(3) 엉치뼈 기울임 변화}

The Polhemus Liberty (Polhemus Liberty, Colchester, VT, USA)를 전자 기적 동작 분석기기로 사용하였다. 엉치뼈의 후방 기울임 각도를 측 정하기 위해 사용되었고, 2 번째 엉치뼈 가시돌기 부분에 마그네틱 센 서를 부착하였다. 모션 아티팩트를 조절하기 위해 센서를 동일한 부 위에 표시하고 견고하게 고정했다. 동작 분석 기기를 사용해서 3 차원 의 위치와 방향을 측정하였다. 데이터는 개인용 컴퓨터에 기록되고 $120 \mathrm{~Hz}$ 의 샘플링 속도로 처리되었다. 소스와 센서의 방향은 $X$ 축은 전 방(forward), Y축은 우측(right) 및 Z축은 상방(up)으로 좌표계로 정의 되었다. ${ }^{19}$ 측정 신뢰도는 0.94 이다. ${ }^{19}$ 2번째 엉치뼈의 가시 돌기에 1 개 의 센서를 부착하여 엉치뼈 기울임을 각각 측정했다.

대상자들이 앉아서 30 분간 타이핑 작업을 수행하는 동안 시상면 을 기준으로 변화된 값을 계산하였다. 데이터는 동작분석 장치에 의 해 $120 \mathrm{~Hz}$ 의 샘플링 주파수로 타이핑 작업을 시작하기 전 1 분과 완료 한 후 1 분 값을 받아서 평균을 냈다. 모든 대상자는 검사의 시작 위치 에 대해 선호하는 자세로 평소처럼 앉았다. ${ }^{19}$

엉치뼈 기울임은 시상면을 기준하여 1자유도(굽힘-폄 각도)에 대 한 변수를 관찰하여 측정했다. 수직(중력) 방향을 기준하여 상대적인 2 번째 엉치뼈의 기울임 각도 값은 부착된 센서의 기울임에 대한 정보
를 수집하였다. ${ }^{20}$ 음의 각도는 후방 엉치뼈 기울임을 나타내고, 양의 각도는 전방 엉치뼈 기울임을 나타낸다. 자세의 변화는 시상면을 기 준으로 기울임의 변화값을 결정하기 위해 시작 전과 완료 후 이동값 을 계산하여 정하였다.

\section{(4) 압력센서를 이용한 시각적 바이오 피드백}

이 연구에서 이용한 압력메트(Baltube, RELIVE, Gimhae, Korea)는 앉 은 자세에서 엉덩부위로 전달되는 압력을 센서를 통해서 감지하여 시각적으로 바이오 피드백을 제공할 수 있는 장비이다. 압력메트의 크기는 $25 \mathrm{~cm} \times 25 \mathrm{~cm} \times 7 \mathrm{~cm}$ 로 구성되어 있고, 총 4 개의 공기압 챔버 로 구성되어 있다. 1 번과 3 번 챔버는 압력메트의 뒤쪽에 배치되어 엉 덩이 오른쪽(1번)과 왼쪽(3번)의 압력을 감지한다. 2 번과 4 번 챔버는 압력메트의 앞쪽에 배치되어 허벅지 오른쪽(2번)과 왼쪽(4번)의 압 력을 감지한다(Figure 1). ${ }^{18}$ 실험자는 대상자가 양쪽 엉덩이와 허벅지 의 위치가 압력메트 각각의 챔버 위에 바르게 위치할 수 있도록 해준 다. 각각의 챔버는 앉은 자세에서 전달되는 압력 수치를 감지하면서, 최대 압력은 $999 \mathrm{mmHg}$ 까지 감지한다. 각각의 챔버의 안정성을 위해 $150 \mathrm{mmHg}$ 이상 압력이 증가할 경우 자동적으로 압력센서의 가동이 멈추게 된다. ${ }^{18}$ 압력메트는 컴퓨터와 연결되어 조절되며, 타이핑을 수 행하면서 총 4 개의 공기압 챔버에서 실시간으로 감지되는 압력 수치 에 대해서 모니터를 통한 그래프를 통해 시각적 바이오 피드백을 제 공받게 된다. ${ }^{18}$

허리골반 부위가 한쪽 방향으로 치우쳐 있지 않으며, 적절한 허리 뼈 앞굽음을 유지하고, 편안하게 몸통을 세운 자세를 중립 앉은 자세 로써 기준으로 하였다. 그리고 중립 앉은 자세에서 골반경사 측정기 를 이용하여 시상면에서 위앞엉덩뼈가시와 위뒤엉덩뼈가시의 각도 를 $0^{\circ}$ 에 맞추고 타이핑을 시작했다(Figure 2). 앉은 자세에서 처음 타 이핑을 수행하면서부터 초기값에서 시상면을 따라 후방으로 허리골 반 부위가 기울어질 경우, 양쪽 엉덩부위와 허벅지에서 감지되는 1-4 번 챔버의 압력수치 중에서 1,3 번 챔버의 압력 증가에 대해 시각적 바

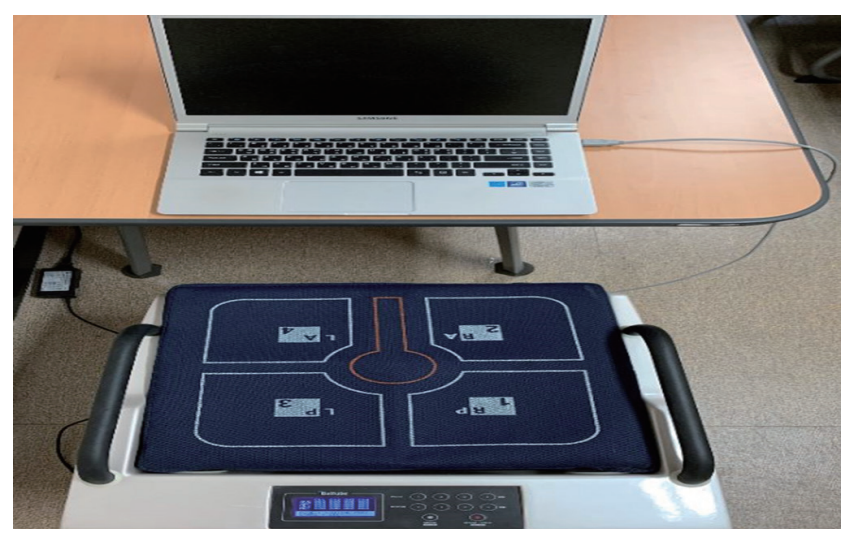

Figure 1. Visual biofeedback with pressure mat. 


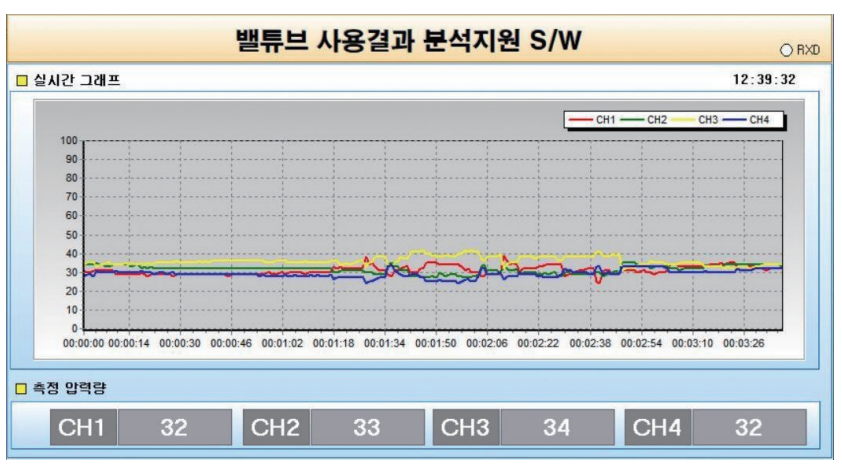

Figure 2. Pressure visual biofeedback for neutral sitting posture.

Table 2. Comparison of the changing value (end value-initial value) of the multifidus muscle activity in subjects with and without biofeedback

\begin{tabular}{lcccc}
\hline Variables & $\begin{array}{c}\text { Biofeedback } \\
\text { group }\end{array}$ & $\begin{array}{c}\text { Non biofeedback } \\
\text { group }\end{array}$ & $\mathrm{t}$ & $\mathrm{p}$ \\
\hline Sub-MVIC (\%) & $6.85 \pm 3.35$ & $-12.18 \pm 5.25$ & -6.12 & $<0.05^{*}$ \\
\hline
\end{tabular}

${ }^{*} p<0.05$, Mean \pm Standard deviation, (-) negative values indicate posterior tilting.

이오 피드백이 제공된다(Figure 3). 따라서, 비특이성 요통이 있는 대 상자들이 30 분 동안 앉은 자세에서 타이핑 작업을 수행하면서, 시각 적 바이오 피드백 제공 그룹에서는 중립 앉은 자세를 기준으로 뒤쪽 방향으로 압력 변화가 발생했을 때 시각적 바이오 피드백을 통해 다 시 초기 자세로 수정할 수 있게 된다. 반면, 시각적 바이오 피드백 비 제공 그룹에서는 타이핑 작업을 수행하는 30 분 동안 어떠한 피드백 도 제공하지 않았다.

\section{3. 실험 절차}

책상과 의자는 높이 조절 가능한 것으로 사용하였다. 몸통 부위와 나란히 팔꿈치 굽힘 각도가 $90^{\circ}$ 가 될 때까지 의자와 책상 높이를 조 절하였다. 각도기를 이용해 엉덩관절과 무릎관절 각도를 측정했다. 의자는 시작 위치에서 바닥에 고정된 발에서부터 엉덩관절과 무릎 관절이 $90^{\circ}$ 가 되도록 조정했다..$^{20}$ 실험 그룹은 노트북으로 타이핑을 시작하기 전에 압력센서를 이용한 시각적 바이오 피드백에 적응하였 다. 노트북 상에서 시각적 바이오 피드백 프로그램은 화면의 하단에 배치하였고, 타이핑을 위한 문서 프로그램은 화면의 상단에 배치해 서, 타이핑 작업을 수행하면서 한 노트북 화면 상에서 시각적 바이오 피드백을 제공받을 수 있도록 하였다.10,18 노트북은 책상 가장자리에 서부터 $10 \mathrm{~cm}$ 거리에 위치하였다. 두 그룹 모두 바닥에 발로 편안하게 둘 수 있도록 발판을 제공하였다. 대상자들은 30 분 동안 타이핑을 진 행했다. 근전도 데이터 및 3 차원 측정 데이터는 두 번(타이핑 작업 시 작 전과 30 분작업 후) 기록되었다.

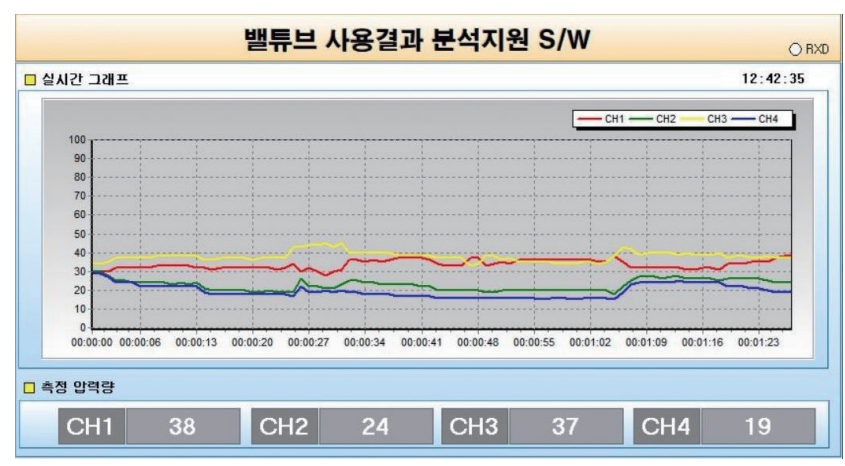

Figure 3. Pressure visual biofeedback for pelvic posterior tilt sitting posture.

\section{4. 자료 분석}

통계 분석용 프로그램인 IBM SPSS statistics 18.0 (SPSS Inc, Chicago, IL) 을 사용하였다. 데이터 정규성 평가를 위해 Kolmogorov-Smirnov 검 정을 사용했다. 독립표본 t-검정(Independent t-test)을 이용하여 바이 오 피드백 적용 그룹과 비적용 그룹 사이에서 뭇갈래근 근활성도, 골 반 그리고 2 번째 엉치뼈 기울임 각도의 변화값(changing values, 말기 값-초기값에 대한 변화량)에 대한 그룹별 비교분석을 실시했다. 통 계적 유의수준은 $\mathrm{p}<0.05$ 로 설정하였다.

\section{결 과}

뭇갈래근 근활성도, 골반 기울임 각도 그리고 2 번째 엉치뼈 기울임 각도에서 바이오 피드백 제공그룹과 비제공그룹 사이의 초기값에서 통계학적으로 유의한 차이는 없었다( $\mathrm{p}>0.05)$.

\section{1. 뭇갈래근 근활성도}

30 분간 타이핑 작업을 수행하면서 바이오 피드백 제공그룹에서 뭇 갈래근의 근활성도의 변화값은 비제공 그룹에서보다 통계학적으로 유의하게 작았다 $(\mathrm{p}<0.05)$ (Table 2).

\section{2. 골반 기울임 각도}

30 분간 타이핑 작업을 수행하면서 바이오 피드백 제공그룹에서 골 반 기울임 각도의 변화값은 비제공 그룹에서보다 통계학적으로 유의 하게 작았다 $(\mathrm{p}<0.05)($ Table 3$)$.

\section{2번째 엉치뼈 기울임 각도}

30 분간 타이핑 작업을 수행하면서 바이오 피드백 제공그룹에서 2 번 째 엉치뼈 기울임 각도의 변화값은 비제공 그룹에서보다 통계학적으 로 유의하게 작았다 $(\mathrm{p}<0.05)($ Table 4$)$. 
Table 3. Comparison of the changing value (end value-initial value) of the pelvic tilting angle in subjects with and without biofeedback

\begin{tabular}{lccccc}
\hline Variables & $\begin{array}{c}\text { Biofeedback } \\
\text { group }\end{array}$ & $\begin{array}{c}\text { Non biofeedback } \\
\text { group }\end{array}$ & $\mathrm{t}$ & $\mathrm{p}$ \\
\hline Pelvic tilting angle $\left(^{\circ}\right)$ & $4.29 \pm 2.03$ & $-13.15 \pm 3.13$ & -4.85 & $<0.05^{*}$
\end{tabular}

${ }^{*} \mathrm{p}<0.05$, Mean \pm Standard deviation, (-) negative values indicate posterior tilting.

\section{고 찰}

본 연구는 비특이성 요통 환자가 30 분 동안 타이핑 작업을 수행하는 동안 뭇갈래근 근활성도, 골반 그리고 2 번째 엉치뼈 기울임 각도 변 화값에 대해서 바이오 피드백 제공이 미치는 영향에 대해서 조사하 였다. 본 연구에서 그룹 간에 통계학적으로 유의한 차이를 확인하였 는데, 시각적 바이오 피드백을 제공한 그룹에서는 30 분간 타이핑 작 업을 수행하는 동안 허리골반부위의 움직임이 시상면을 기준으로 경미한 후방 기울임을 보인 채 처음 타이핑 시작 자세에서 큰 변화가 없었고, 뭇갈래근 근활성도도 큰 변화 없이 유지하였다. 시각적 바이 오 피드백을 제공하지 않은 그룹에서는 제공한 그룹에 비해서 30 분 동안 타이핑 작업을 수행하는 동안 뭇갈래근의 근활성도 및 골반 그 리고 2번 엉치뼈 기울임 각도의 큰 변화를 확인할 수 있었다.

시각적 바이오 피드백 유무에 따라서 허리골반 부위의 움직임과 뭇갈래근 근활성도 변화에 차이가 있는 이유는 다음과 같이 생각해 볼 수 있다. 앉은 자세에서 허리골반 부위에 대한 고유수용성 감각 정 보의 손상을 고려해 볼 수 있다. 선행 연구를 보면, 비특이성 요통 환 자는 중립 자세로 앉아 있는 상태에서 자세를 변경한 뒤, 다시 허리뼈 를 정확하게 중립으로 재위치(repositioning)할 수 있는 능력이 떨어진 다고 보고하였다. ${ }^{21}$ 앉은 자세는 엉치뼈를 포함한 골반의 위치, 기울임 과 연관이 있고, 이러한 요소들이 허리뼈 앞굽음에도 영향을 미친 다. ${ }^{22}$ 이와 같은 맥락으로 비특이성 요통 대상자는 신체 도식(body schema)의 변화와 고유수용성 정보의 손상이 있기 때문에 오랜 시간 동안 앉은 자세에서 타이핑 작업을 수행하면서, 허리뒤굽음과 골반 후방 기울임이 발생하더라도 그 자세에 대한 고유수용성 정보가 손 상되었고, 부족하기 때문에 곧게 선 자세로 다시 변화시키기 훨씬 어 렵다고 볼 수 있다. ${ }^{23}$ 본 연구에서도 시각적 바이오 피드백을 제공하 지 않은 그룹은 앉아 있는 자세에서 30 분간 타이핑 작업을 수행하는 동안 골반과 엉치뼈의 후방 기울임 증가는 고유수용성 감각 정보를 충분히 제공받지 못한 것이 이 연구 결과의 원인이 될 수 있다.

시각적 바이오 피드백을 제공한 그룹에서는 비특이성 요통 환자 그룹임에도 불구하고, 30 분 동안 타이핑 작업을 수행하는 동안 시상 면을 기준으로 1 번과 3 번 챔버의 압력이 증가되면서 후방 기울임이 감지되었을 때 시각적 바이오 피드백을 제공하면서, 부족한 허리골 반부위의 고유수용성 감각 정보에 시각적으로 도움을 준 것으로 해
Table 4. Comparison of the changing value (end value-initial value) of the 2 ndsacrum angle in subjects with and without biofeedback

\begin{tabular}{lcccc}
\hline Variables & $\begin{array}{c}\text { Biofeedback } \\
\text { group }\end{array}$ & $\begin{array}{c}\text { Non biofeedback } \\
\text { group }\end{array}$ & t & $p$ \\
\hline $\begin{array}{c}\text { 2nd Sacrum tilting } \\
\text { angle }\left(^{\circ}\right)\end{array}$ & $5.17 \pm 3.03$ & $-15.13 \pm 5.13$ & -7.64 & $<0.05^{*}$ \\
\hline
\end{tabular}

${ }^{*} \mathrm{p}<0.05$, Mean \pm Standard deviation, (-) negative values indicate posterior tilting.

석될 수 있다. 엉치뼈의 후방기울임이 증가되어 1 번과 3 번 챔버의 압 력이 증가되는 것을 시각적 바이오 피드백으로 실시간 제공되었기 때문에, 제공하지 않은 그룹에 비해서 작업시간 동안 골반과 2번 엉 치뼈 후방 기울임 각도가 변화되지 않은 것으로 해석된다. 따라서, 시 각적 바이오 피드백이 제공되었기 때문에, 비특이성 요통 환자들이 타이핑을 30 분간 수행하면서 중립으로 앉은 자세를 유지하는 것에 도움을 줄수 있었다.

뭇갈래근 근활성도의 경우 시각적 바이오 피드백을 제공한 그룹 에서 30 분간 타이핑을 수행하는 동안 근활성도를 유지한 반면에 제 공하지 않은 그룹에서는 시간이 지남에 따라 근활성도의 큰 감소를 확인할 수 있었다. 비특이성 요통이 있는 환자의 경우 장시간 동안 앉 은 자세를 취할 경우 구부정하게 앉는 자세로 변하는 경향이 있다.22 따라서 구부정한 자세로 타이핑을 수행하면서 허리앞굽음은 시상면 을 기준으로 감소하고, 골반 후방 기울임이 발생하는 것을 확인할 수 있었다. 이에 따른 허리뼈의 자세 역시 뒤굽음으로 변하면서, 뭇갈래 근이 신장된 자세(lengthened position)에 위치되면서, 뭇갈래근의 근 활성도를 감소시킨 것으로 확인된다. 따라서 구부정한 자세에서 엉 치뼈와 골반 부위의 굽힘 자세가 중립 범위(neutral zone)를 넘어서 마 지막 범위(end range)까지 증가되면서, 능동적 수축조직인 뭇갈래근 은 신장된 자세가 된 것이다. 이에 따라 뭇갈래근의 근활성도는 최소 화되고, 비수축조직인 인대의 장력이 더 크게 관여하게 된 것으로 보 여진다. 하지만 시각적 바이오 피드백이 제공되면서 골반허리부위의 고유수용성 감각정보를 향상시킴으로써, 구부정한자세를 최소화시 키고, 다시 원래의 중립자세로 재위치할 수 있었다.11,22 앉은 자세에서 2 번 엉치뼈 기울임이 후방으로 넘어갔을 때 시각적 바이오 피드백의 제공으로 인해서 뭇갈래근의 근활성도가 유지될 수 있는 이유는 엉 치뼈를 중립 범위 이내로 위치시킴으로써 뭇갈래근의 근육 활성화 를 유지할 수 있었기 때문이라고 생각된다. ${ }^{24}$ 선행연구에서도 30 분 동 안 앉은 자세 동안에 허리골반 부위에 자세 테이핑을 적용하였을 때 적용하지 않은 그룹에 비해서 뭇갈래근 근활성도 유지에 도움이 되 는 결과를 발표하였다. ${ }^{9}$ 본 연구에서는 선행연구에서 제공한 자세 테 이핑 적용과는 다른 시각적 바이오 피드백 제공이지만, 허리골반부 위에 고유수용성 감각정보를 향상시킬 수 있는 방법을 이용했다는 점에서 동일한 결과를 확인할 수 있었다. 
결론적으로 본 연구에서는 30 분간 타이핑을 수행하는 동안 시각 적 바이오 피드백 제공으로 인해서 비특이성 요통이 있는 대상자에 게 뭇갈래근 근활성도, 골반 그리고 2 번째 엉치뼈 기울임 각도 변화 값이 감소되는 것을 확인할 수 있었다. 따라서 앉은 자세에서 타이핑 을 수행하면서 비특이성 요통 대상자가 뭇갈래근 근활성도와, 골반 그리고 2 번째 엉치뼈 기울임 각도를 유지하게 위해서 시각적 바이오 피드백 제공이 추천된다.

본 연구의 제한점은 다음과 같다. 첫째, 비특이성 요통 환자에 대한 진단학적 구분을 상세히 적용하지 않았다. 추후 연구에서는 요통 원 인에 따른 시각적 바이오 피드백 제공 유무가 영향을 미치는지에 대 한 조사가 필요하다. 둘째, 본 연구에서는 젊은 비특이성 요통 환자를 참여시켰다. 후속 연구에서는 연령대에 따른 추가 조사가 필요하다. 셋째, 시각적 바이오 피드백 제공 시간이 타이핑 작업을 수행하는 30 분간만 진행되었다. 추후 연구에서는 직업적으로 컴퓨터 사용하는 작업자가 근로하는 시간(약 8 시간 이상)에 따른 조사가 필요하다. 넷 째, 본 연구에서는 앉은 자세 변화에 대한 동작 분석을 골반과 엉치뼈 에 대해서만 분석하였다. 추후 연구에서는 등뼈 부위까지 포함한 분 석이 필요하다. 다섯째, 본 연구에서는 등받이가 있는 의자를 사용하 지 않았다. 추후 연구에서는 등받이 여부에 따른 근활성도와 앉은 자 세 변화에 대한 비교 연구가 필요하다.

\section{ACKNOWLEDGEMENTS}

본 연구는 산업통상자원부와 한국산업기술진흥원의 “지역산업거점 기관지원사업”(과제번호: R0006231)으로 수행된 연구임.

\section{REFERENCES}

1. O'Sullivan PB, Dankaerts W, Burnett AF et al. Effect of different upright sitting postures on spinal-pelvic curvature and trunk muscle activation in a pain-free population. Spine. 2006;31(19):E707-12.

2. Lee JH, Yoo WG. The mechanical effect of anterior pelvic tilt taping on slump sitting by seated workers. Ind Health. 2011;49(4):403-9.

3. Claus A, Hides J, Moseley GL et al. Sitting versus standing: does the intradiscal pressure cause disc degeneration or low back pain? J Electromyogr Kinesiol. 2008;18(4):550-8.

4. Makhsous M, Lin F, Bankard J et al. Biomechanical effects of sitting with adjustable ischial and lumbar support on occupational low back pain: evaluation of sitting load and back muscle activity. BMC Musculoskelet Disord. 2009;10(1):17.

5. Burnett AF, Cornelius MW, Dankaerts W et al. Spinal kinematics and trunk muscle activity in cyclists: a comparison between healthy controls and non-specific chronic low back pain subjects-a pilot investigation. Man Ther. 2004;9(4):211-9.

6. Dankaerts W, O'Sullivan P, Burnett A et al. Differences in sitting postures are associated with nonspecific chronic low back pain disorders when patients are subclassified. Spine. 2006;15;31(6):698-704.

7. O'Sullivan K, O'Sullivan L, O'Sullivan P et al. Investigating the effect of real-time spinal postural biofeedback on seated discomfort in people with non-specific chronic low back pain. Ergonomics. 2013;56(8):131525.

8. O'Sullivan PB, Burnett A, Floyd AN et al. Lumbar repositioning deficit in a specific low back pain population. Spine. 2003;28(10):1074-9.

9. Kim HA, Kwon OY, Ahn SH et al. Effect of taping on lumbar kinematics and muscle activities during typing in Individuals with nonspecific chronic low back pain. Phys Ther Korea. 2015;22(1): 93-102.

10. Cho MS, Park KN, Choung SD et al. Effect of visual biofeedback training in real time on buttock pressure and pelvic tilting angles of hemiplegic patients during sitting. Phys Ther Korea. 2017;24(2):66-75

11. Kang MH, Choi SH, Oh JS. Postural taping applied to the low back influences kinematics and EMG activity during patient transfer in physical therapists with chronic low back pain. J Electromyogr Kinesiol. 2013; 23(4):787-93.

12. Leitner C, Mair P, Paul B et al. Reliability of posturographic measurements in the assessment of impaired sensorimotor function in chronic low back pain. J Electromyogr Kinesiol. 2009;19(3):380-90.

13. Marshall P, Murphy B. Delayed abdominal muscle onsets and self-report measures of pain and disability in chronic low back pain. J Electromyogr Kinesiol. 2010;20(5):833-9.

14. Sahrmann SA. Diagnosis and treatment of movement impairment syndromes. St Louis, Mosby, 2002:111-21.

15. Kim YW, Kim TH, Yang MN et al. Comparison of activities of tibialis anterior, peroneus longus, and tibialis posterior muscles according to lunge squats and bulgarian split squats in a healthy population. J Musculoskelet Sci Technol. 2017;1(1):26-30.

16. Jung EJ, Oh JS. Effects of indirect pelvic floor muscle activation exercise using a pressure biofeedback unit on trunk muscle activity in sitting position. J Musculoskelet Sci Technol. 2020;4(1):18-24.

17. Dankaerts W, O'Sullivan PB, Burnett AF et al. Reliability of EMG measurements for trunk muscles during maximal and sub-maximal voluntary isometric contractions in healthy controls and CLBP patients. J Electromyogr Kinesiol. 2004;14(3):333-42.

18. Kim JS, Kang MH, Moon DC et al. Effect of pelvic tilt exercise using pressure-based visual biofeedback training on the gait parameter in elderly patients with Alzheimer's disease. Eur Geriatr Med. 2017;8(1):30-6.

19. Burnett AF, Barrett CJ, Marshall RN et al. Three-dimensional measurement of lumbar spine kinematics for fast bowlers in cricket. Clin Biomech. 1998;13(8):574-83.

20. Dolan P, Greenfield K, Nelson RJ et al. Can exercise therapy improve the outcome of microdiscectomy? Spine. 2000;25(12):1523-32.

21. O'Sullivan PB, Burnett A, Floyd AN et al. Lumbar repositioning deficit in a specific low back pain population. Spine. 2003;28(10):1074-9.

22. Vaz G, Roussouly P, Berthonnaud E et al. Sagittal morphology and equilibrium of pelvis and spine. Eur Spine J. 2002;11(1):80-7.

23. O'Sullivan K, McCarthy R, White A et al. Can we reduce the effort of maintaining a neutral sitting posture? A pilot study. Man Ther. 2012; 17(6):566-71.

24. Panjabi MM. The stabilizing system of the spine. Part II. Neutral zone and instability hypothesis. J Spinal Disord. 1992;5(4):390-6. 